\title{
Trust in the context of audience fragmentation
}

\author{
Ragne Kõuts ${ }^{1}$
}

Institute of Journalism and Communication, University of Tartu, Estonia

Peeter Vihalemm²

Institute of Journalism and Communication, University of Tartu, Estonia

Marju Lauristin ${ }^{3}$

Institute of Journalism and Communication, University of Tartu, Estonia

\section{doi:10.5937/comman1326099K}

Summary: The growing complexity of today's societies in combination with increasing audience fragmentation makes the question 'what is holding society together?' more important than ever. If 'trust' is the primary 'cement' used in the building of an operational communicative network without personal contacts and face-to-face communication, do we see changes in trust patterns going hand in hand with increasing social diversity and fragmented media?

In this article we will examine the connections between trust, media usage and social participation. In the first part we will analyse the general societal context and trust in European societies, based on Eurobarometer surveys, highlighting cultural/national specifics. We will then concentrate on those general social factors that illuminate the patterns of social participation and media usage, and show interconnections between these factors and trust levels. In order to make this study as comprehensive as possible, our study of Estonia will be discussed in detail.

Keywords: institutional trust, media, audience fragmentation, Estonia, Eurobarometer

\footnotetext{
1 ragne.kouts@ut.ee

2 peeter.vihalemm@ut.ee

3 marju.lauristin@ut.ee
} 


\section{Trust and media: two research traditions}

In the history of media research, one can distinguish two research traditions that deal with trust and mass media. With regard to media effects, traditional researchers have tried to connect mass media content and/or media use with social and political trust. Cultivation analyses show an evolution towards rising levels of negativism in the content, and researchers argue that mass media will cultivate even more cynicism among audiences (as argued by Gerbner and his team in 1969, or Wolling in 2001). Researchers from this school have concluded that the frequent exposure of political scandals, corruption, natural disasters and crime-related news by the mass media will also create an environment of more uncertainty and distress for the audiences.

The other approach to this research deals with trust in the institution of mass media itself, or institutionalised trust (Sztompka, 1999; Quandt, 2012). Some researchers have shown historical trends that proceed towards a greater degree of mistrust on the part of the audiences (Cappella, 2002: 231). For example, media scepticism in America has grown from 15\% in 1973 to $41 \%$ in 1996 (Tsafti, 2001 cit. in Cappella, 2002), in keeping with the growing atmosphere of mistrust in American society (see Putnam, 2000).

It is clear that on a general level of institutional trust, real political and social events and cultural contexts also influence trust in the mass media, however the same concept can be identified in the opposite direction: "if trust in media is dwindling, this also becomes a danger to society at large, as there is no other reliable structure that could provide the necessary reduction of complexity for society" (Quandt, 2012: 18).

Applying Piotr Sztompka's model of multi-layered institutional trust (Sztompka, 1999), we can differentiate between a general level of symbolic trust in the 'media as such', which is dependent on the level of general trust in institutions in the given society, and the "procedural trust", which is more closely related to the real experiences of people's dealings with particular institutions. Quandt has argued that institutional trust "is a more generalised, 'thin' trust or even 'systemic' trust (as in the belief of the general functioning of the whole network, its rules and its actors)" (Quandt, 2012: 12). Thus, not only personal experiences play a role in institutional trust, but the importance of perceived trustworthiness is also decisive - people should believe that an institution is trustworthy.

European surveys have shown that among the institutions, any type of mass medium is trusted more by the population than parliaments or governments in 
nation states (Standard Eurobarometer, 2009, 2011). This is probably related to the role that the media have played in the region's history. "The media have been seen in Europe for most of the twentieth century, as first social institutions and only secondary, if at all, private business" (Hallin \& Mancini, 2004: 49). The general feature of media in Europe could be an assumption that media, and especially the printed press, represent the public more than commercial or private interests (see e.g. 'Four theories of press'-tradition beginning with Siebert et al. (1963) - well summarised by Jakubowitz, 2010). However, commercialisation is a trend that is also noticeable in European media systems (McQuail, 2007), and even public broadcasting services have not remained untouched by this process (Jóesaar, 2011).

Nevertheless, identifying a clear criterion in order to measure the trustworthiness of an institution is a complicated task "because the appraisal of their trustworthiness usually requires simultaneous consideration of various scales of achievement, and the scales are most often incommensurable" (Sztompka, 1999: 83). This is one of the reasons why, in sociological research, the decisions regarding the question 'does one trust or not' are left to respondents and the question is asked directly in the surveys - researchers trust the answers of the respondents. However, studying the reasons as to why one trusts an institution or not is a more complicated task for researchers. Delhey and Newton (2002) used the Eurobarometer studies in seven countries to test which origins of social trust can be considered as the most important. Is a more trusting attitude related to personality type, to a higher income and social status, or does it derive from membership in voluntary associations or from having a larger social network? Is it related to the physical location of a given individual's home and the size of the surrounding community, or to absence of social conflicts in society? These scholars conclude that

"generalised social trust tends to be high among citizens who believe that there are few severe social conflicts and where the sense of public safety is high. Second, membership of informal social networks is significant in all countries. And third, those who are successful in life can afford to trust more" (Delhey \& Newton, 2002: 22).

Quite similarly, as in the case of generalised trust, trust in different media channels is also embedded in the relevant social context. According to Eurobarometer 2011, there are considerable differences in news media preferences, as well as in the level of trust in particular channels, which depend on age, gender, economic performance and professional background. In Europe 
"the respondent's level of education also creates significant differences: for example, trust in radio, the press and the internet increases in line with respondent's level of education /.../ The opposite is true as regards television: the least educated respondents are more likely to trust it. Trust levels are lower among respondents with financial difficulties" (Media Use in the EU - Autumn, 2011: 13).

\section{Trust in Europe}

Generalised institutional trust is unevenly distributed across the globe (Delhey \& Newton 2005: 1). Comparing trust in politicians, parliament or the president, with few exceptions one can distinguish the more trusting Northern Europe from the less trusting South, and the more trusting 'old' EU countries from the less trusting 'newcomers' (Standard Eurobarometer, 2006, 2011). After the collapse of the Soviet Union, post-communist countries have shown decidedly lower trust levels in comparison to those of stable democratic countries (Sztompka, 1995; Mishler \& Rose, 2001; Lovell, 2001; Delhey, \& Newton, 2002), and twenty years after the collapse of the 'red' regime this is still the case. For example, 58\% of Finland's inhabitants trusted parliament and 56\% trusted government in 2011, whereas in Romania the respective percentages were 9 and 10 (Standard Eurobarometer, 2011).

Trust in media and trust in state institutions are all correlated in Europe, however the direction of these correlations differ, dividing the European countries into distinguishable groups (Figure 1). Both high trust in media and high trust in state institutions are characteristic of Nordic countries such as Sweden, Finland and Denmark. Somewhat lower political trust, but comparably high trust in the media is found in the second group comprised of countries such as Austria, The Netherlands and Germany, as well as new EU members such as Estonia and Bulgaria. The third group is characterised by a moderate level of trust in both fields compared to the EU average, taken in France, Portugal, UK, Spain, Ireland and the post-communist countries including Latvia, Poland, Lithuania and Hungary. The last group, where media trust and political trust are both very low, is made up of Greece, Italy and Malta. In Italy trust has been low for many decades, yet in Greece an abrupt decline was registered in recent years, when the economic difficulties of the state became public knowledge. 
Figure 1: Trust in media and state institutions in European countries, 2011

(Source: Eurobarometer, 2011). ${ }^{4}$

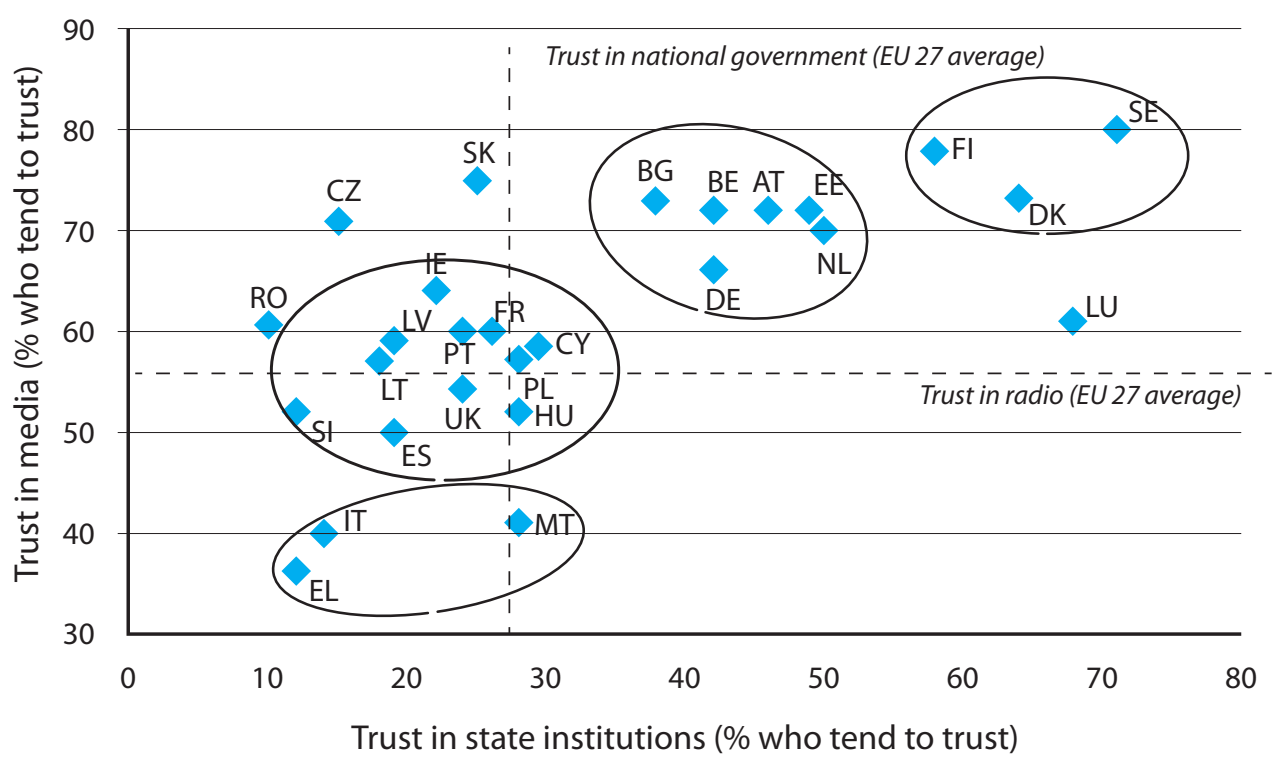

In the context of trust in the media, the post-communist states do not form a unified group - while the local public trust in mass media has increased in some post-communist countries such as Estonia, Poland or Hungary over the last few years, it has also grown in Nordic countries such as Finland, Sweden and Denmark. At the same time, this trust has decreased significantly in Portugal and Greece. Data provided by the Eurobarometer show that European countries have followed different patterns.

Trust displayed towards different media types or channels is also different. Among all of the media types, in Europe, broadcasting services are more trusted than newspapers or internet. This is probably related to the media policy in Europe, where one of "the basic principles was, applying mainly to broadcasting, that of maintaining a public service element in communication to ensure certain essential benefits to the society as a whole and its constituent groups"

\footnotetext{
4 Since the role of specific media types varies according to different countries' realities, the percentages of the most trusted media type (TV or radio) are given in the graph above (figure 1), and are based on the same considerations, as are the most trusted state institutions (government or parliament). Positions reported in this graph are compared to the EU average in both dimensions (in 2011, from the mass media types, radio is more trusted than TV - respectively $57 \%$ and $53 \%$ tend to trust; from the state institutions, national parliaments are more trusted than governments - respectively $27 \%$ and $23 \%$ of Europeans tend to trust).
} 
(McQuail, 2007: 22). There are however significant differences between countries, and this system is changing. An especially significant indicator related to changes in European media systems could be the decreasing role of printed media in many countries. Compared to public trust in broadcasting, the printed press is significantly less trusted for example in United Kingdom, Sweden, Denmark and Bulgaria. Trust ratings for the press are highest in Finland, Slovakia and Luxembourg.

In the majority of countries traditional media are more trusted than the internet. The situation is interesting in Greece and Italy, where the internet enjoys almost the same or even a higher level of trust in comparison to broadcasting or print media. In Czech Republic, Denmark and Slovakia, more people trust the internet than the press. The internet as a 'newcomer' is only slowly establishing itself and growing in terms of its trustworthiness, though its usage has increased more quickly than trust in the actual resource.

It is not easy to generalise patterns in media trust. On the one hand, it is related to the cultural specificities and historically rooted role of different media types in the respective cultures, but on the other hand, it is also probably influenced by paradoxical situations in institutionalised mass media:

"media houses - and journalistic media in particular - rely on trust in their content which is produced according to professional rules and tries to be 'truthful' to the actual events (factuality); however, the institutionalised, rule-based 'production' - which is supposed to guarantee factuality - actually feeds doubts about the 'authenticity' of the content" (Quandt, 2012: 17).

Although Eurobarometer findings should be interpreted with care, they are valuable sources in establishing the generality of our findings derived from single contexts. "The need for international comparison is more evident in the areas where we find a strong relationship between communication phenomena, on the one hand, and political systems and cultural value systems, on the other" (Esser \& Hanitzsch, 2012: 4).

One would expect that, when talking about trust in the media, we should take into account two viewpoints on institutional trust: firstly, the image or reputation of channels in a given society, and secondly, the real usage, or procedural trust according to Sztompka (1999). Here we will test these concepts using one national example, i.e. that of Estonia. 


\section{Audience fragmentation}

As an instrument to be used in the analysis of the foundations of media trust, the Eurobarometer survey is too general, as among particular media type we face highly complex realities: commercial vs. public service principles; more informative and more entertaining content; consumer-oriented vs. citizenoriented content, etc. Nowadays, as a result of the greater availability of communication technologies, audiences can choose freely between many different channels in order to compile their personal 'media menus'. Given that a larger selection is delivered by broadband networks and more choices are available 'on-demand', patterns of consumption have become more widely distributed (Webster \& Ksiazek, 2012: 39). Although audience fragmentation is often dealt with in the context of digital media (Chaffee \& Metzger, 2001; Tewksbury, 2005), we see that fragmentation in traditional media is just as important in the current situation (Vihalemm, 2008). "With further growth and complexity, the problems of a 'traditional' media system become exacerbated: if the social structure becomes more fragmented into segregated subgroups, without a larger unified core (mainstream), it becomes harder for media to address all the interests and communication needs" (Quandt, 2012: 13).

For some researchers, "fragmentation spells the end of a common cultural forum, or worse, the birth of media enclaves and 'sphericules' that scarcely interact" (Webster \& Ksiazek, 2012: 39). Fragmentation is thus conceptualised as a counter-process for integration. Modern sociological theories have noticed the development of highly differentiated and disintegrated societies (Heitmeyer, 1997; Luhmann, 2002); at least this is the case in Europe. However, if we prefer to adopt a more complex audience-centric approach to fragmentation, as Webster and Ksiazek do, "we find very little evidence that audiences are composed of devoted royalists; rather, they show high levels of overlap across outlets" (Webster \& Ksiazek, 2012: 40). Based on one national example, Vihalemm concludes that "the uses of traditional and new media are in general complementary to each other" (Vihalemm, 2008: 119). Among media audiences, we do not find a clear polarisation between young people who are predominantly internet users, and users of traditional media channels. Thus we define fragmentation as a situation in which there is no single core or clearly dominating medium in an audience with many subgroups of users, even though their media 'menus' may overlap.

In the context of audience fragmentation, different groups of users are differently involved in society, since their dispositions or participative attitudes 
may differ. We can conceptualise media use as participation, because by consuming mass mediated content, audiences are involved in the communicative network covering all of society. Participation is not only qualified as voting during elections, volunteer work or participation in civic organisations: "sometimes participation is seen as mere presence, and people are seen as participating when they are simply being exposed to specific cultural products (such as watching television, visiting a museum or reading a blog)" (Carpentier \& Dahlgren, 2011: 8). Even minimal involvement needs a respective disposition on the part of the individual. Dahlgren has shown how various forms of media may function in a positive or negative manner in regard to citizens' political involvement in democracy (Dahlgren, 2011: 89). It is more useful to avoid using dichotomist terms in relation to participation and non-participation, while Dahlgren proposes rather a discussion on the intensity of participation (Dahlgren, 2011: 92). Media use alone is only one level and the least intensive mode of participation, but we can also detect gradations in these patterns, as some media need, according to McLuhan, a higher degree involvement for their use (such as reading newspapers) while others require less intensive involvement (such as television) (Gordon, 2003).

Some research has shown links between particular media usage and trusts levels. A study conducted in the US concluded that "reading newspapers and watching entertainment television had positive influences on social trust" (Moy \& Scheufle, 2000: 751), and that the "use of print media can lead to greater political trust because it increases political expertise" (Moy \& Pfau, 2000). A representative longitudinal study in Germany by Schulz (1999) concluded that "mistrust is bigger in the groups who watch more intensively information and entertainment broadcasts and prefer the private channels at the same time" (Schulz, 1999: 100). On the other hand, the diverse use of TV channels creates a feeling of political competency among audiences (Schulz, 1999: 99). These results are important in terms of audience fragmentation, showing how we can test whether media diversity could also be related to differences in trust attitudes. Trust towards media or institutions as individual dispositions can be seen as one of the fragmenting factors. One could assume that groups with clearly different media usage will show different levels of trust and different participative attitudes. 


\section{Research Method}

We used comprehensive survey data collected in Estonia in order to explain the relationships between trust and media use in detail. ${ }^{5}$ Among other variables, the survey contains questions that served the purpose of attempting to 'quantify' the relationship between trust and audience fragmentation.

Here, we will discuss the two approaches used to test the importance of both components in trust levels, i.e. the component of actual use (procedural trust) and the component of trust 'as such' (image or reputation of media), verifying the following research questions:

RQ1: How are media use patterns related to participation and institutional trust?

RQ2: How is trust in the media related to participation?

RQ3: How is trust in the media related to the perceived role of a particular channel?

Our analysis follows a three-step model: firstly, we checked the main determining variables in the trust in media with the help of regression analysis, going on to distinguish between different media use clusters among respondents and describe the socio-demographic composition of clusters. Finally, we related media use patterns with participation and trust variables. Since we assumed that participation, trust and media use have complex interconnections in individual everyday practices - media use becomes one of the participation components, while trust is related to an individual's specific disposition to participate or not - we consciously amalgamated the parameters of media use and participation in the cluster analysis so as to detect the specific combinations of the two aspects. If we clearly detected different media use patterns among respondents, we were then able to describe the situation as audience fragmentation.

For the analysis, we constructed aggregate indexes that measured the intensity and diversity of different types of media usage. Indexes help to give us insight into the activeness and diversity of media use for different groups without

\footnotetext{
A representative survey Me, World and the Media was carried out by the University of Tartu in cooperation with Saar-Poll in November 2011. The survey includes interviews with 1510 respondents aged 15-74; interviews were distributed both in Estonian and in Russian language according to the respondents' preference. The standardised questionnaire contained about 600 questions on media use, lifestyles, political orientations and participation, social values, attitudes, consumption habits, etc. The respondents filled in the greater part of the questionnaire on their own. The research was supported by grants from the Estonian Ministry of Education and Science (No 0180017s07) and the Estonian Science Foundation (No 8329 and 9121).
} 
getting lost in the specifics of each and every media landscape. In our database, we take into account preferences of media use in different language groups, namely those of both Estonians and Russians living in Estonia, who, as users, have significantly different media 'menus' (Vihalemm, 2008).

\section{Media usage clusters in Estonia}

When compared to other European countries, the level of institutional trust in parliament, government and all media types in Estonia is significantly higher than the EU average; it is not only almost the highest among EEC countries, but it is also comparable with 'old' EU countries, although it does not reach the level of Scandinavian nations (Eurobarometer, 2011). In this regard, the survey that we used in the analysis of media usage patterns showed similar results to those cited by Eurobarometer.

In selecting variables and indexes for cluster analysis, we first explored the covariance of many different variables through regression analysis. Media trust was the largest part explained by a constant $(B=1,112)$, and it was significantly correlated with trust in state institutions (Beta 0,509), while it was shown to have only a slight but significant correlation to the activeness and diversity of TV use (Beta 0,021). For this reason, and given that our earlier research supports this model (Lauristin et al., 1987; Kóuts, 2004), we added not only media usage indexes, but also indexes related to trust in state institutions, as well as participation in civic society ${ }^{6}$ to our cluster analysis.

Since we had more than one thousand cases, we used the K-Means cluster analysis method for classifying different types of media use and trust relationships. The results of the cluster analysis allowed us to characterise five distinct patterns (or types) of media usage and relate these media usage types to the social context of audiences, their interests, values, civic participation and trust in the media (Table 1).

\footnotetext{
${ }^{6}$ If we had constructed clusters using only media use indexes, the quality of the model would have been lower than in the case where we included participation indicators as well (we tested the reliability of different models with the help of linear discriminant analysis, as suggested by Everett et al 2001, and took a decision based on this guideline for the model, in which we stipulated three dimensions: media use, trust and the participation dimension).
} 
Table 1: Clusters of media use and participation

(types are listed in order of media use activeness, $n=1510$ ).*

\begin{tabular}{|c|c|c|c|c|c|}
\hline Indexes and variables & Type 1 & Type 2 & Type 3 & Type 4 & Type 5 \\
\hline \multicolumn{6}{|c|}{ Media use indexes, activeness and diversity in: } \\
\hline newspaper reading & ++ & + & ++ & -- & -- \\
\hline radio listening & ++ & ++ & -- & -- & + \\
\hline TV viewing & ++ & + & - & $\varnothing$ & -- \\
\hline internet use & ++ & --- & ++ & $\varnothing$ & - \\
\hline news portal reading & ++ & -- & ++ & - & -- \\
\hline \multicolumn{6}{|l|}{ Civic and political participation indexes } \\
\hline $\begin{array}{l}\text { General interest in politics and politi- } \\
\text { cal participation }\end{array}$ & ++ & ++ & $\varnothing$ & - & -- \\
\hline Participation in civic actions & ++ & ++ & - & $\varnothing$ & -- \\
\hline $\begin{array}{l}\text { Share of cluster among respondents } \\
(\%)\end{array}$ & 22.8 & 17.3 & 13.0 & 17.5 & 29.3 \\
\hline
\end{tabular}

*The marks in the columns indicate the value that a group has in this dimension in comparison to other groups: - - much lower value; - slightly lower value; $\varnothing$ average value; + slightly higher value; ++ much higher value. ${ }^{7}$

We can briefly describe media usage clusters as follows:

1) We describe Type 1 as 'multi-active' ( $23 \%$ of all respondents). Members of this cluster are heavy users of all media channels, both of traditional media as well as internet possibilities. This cluster is also characterised by very active political and civic participation. If we look at trust indicators, we see that this group is the most trustful in both the media and in state institutions, but at the same time is extremely critical towards Estonian media performance. From a socio-demographic point of view, this group consists mostly of highly educated people with high incomes, aged between 30 and 54. In terms of gender, this cluster is proportional to the whole population, but the ethnic composition is

\footnotetext{
In the annexe, the means for clusters are given in comparison to the means for all respondents on the 5-point scale (all differences are significant in the level Sig. = 0.00). The table in the annexe is more detailed and consists of additional variables characterising types of media user, while the socio-demographic composition of groups is also shown.
} 
disproportionally dominated by the Estonian majority (see socio-demographic composition of the clusters in the annexe).

2) Type $2(17 \%)$ is labelled as the 'active traditional user'. This type represents the traditional image of a good citizen. Their activeness and diversity in reading newspapers, watching TV and listening to the radio is higher than average, but internet-related activities are significantly lower than average. On the other hand, they are extremely interested in politics and participate actively in political life and civic society. Their active participation characterises them as having a great deal of trust in state institutions, and their trust in the media is a little higher than average. Socio-demographically speaking, this cluster represents an active part of the older generation: $28 \%$ of this type are retired individuals, with $76 \%$ belonging to the over- 45 age bracket. With regards to income, education and gender, this type is closest to the population average, while in terms of ethnic composition, when compared to their proportion in the whole sample, there are a few more Estonian-speaking respondents than Russian-speaking participants.

3) Type $3(13 \%)$ is labelled as the 'reading-oriented moderate new media user'. This is the smallest group, and while this type is generally more interested in newspapers than in audiovisual media, it also actively uses news portals and reads online newspapers. Broadcasting services are used much less than average by this group. Being moderately interested in political information, this group is simultaneously characterised by a comparatively low civic participation. Its trust in media and state institutions is average. Socio-demographically, this group is dominated by young, highly educated and economically well-off females, who are mainly Estonian-speakers.

4) We labelled Type $4(18 \%)$ as 'moderate TV and internet users'. This type uses both traditional media and news portals less than the average, and only shows some interest in TV and internet. This type is quite passive in relation to political and civic participation. Trust in the media and state institutions is almost average, while criticism towards the Estonian media is the lowest. This is the youngest type (the 15-19 and 20-29 age groups are overrepresented), but the number of Estonian-speakers and Russian-speakers is close to the average of the sample. 
5) Type 5 is the group made up of 'passive public radio listeners' whose radio listening is higher than the sample's average. Politically speaking, this is the most disinterested and less participatory group. Here, trust in the media and in state institutions is also the lowest. Socio-demographically, this group consists mostly of Russian speakers, with a lower level of education and a slightly higher number of males than females, but interestingly, it is very evenly distributed in terms of age structure - in this group we find all age groups in almost the same number as in the sample.

Patterns of audience fragmentation show that it is possible to distinguish between groups of active users of traditional and 'new' media from those groups in which only 'new' media orientation dominates, and those groups in which only traditional media orientation features, and even between groups in which media use is rather low (see Figure 2). However, there are no clear social divisions between more or less active, traditional or new media users, but within the social groups we can see different patterns of media usage.

The same could be said about the relationships between media usage and political participation: even if there are some groups in which active participation goes hand in hand with high media usage (Types 1 and 2), it is also possible to see how comparatively active media users are at the same time less engaged in civic activities and do not participate in political life (Type 3). We cannot state that heavy usage of new media inhibits active participation in real life civic activities, as Type 1 shows the opposite, however, the low level of media usage and low level of participation are more often interrelated than not (Types 4 and 5). 
Figure 2: Media use patterns in different clusters (compared to the averages of all respondents, $n=1510$ ) (differences are significant on the level 0.00).

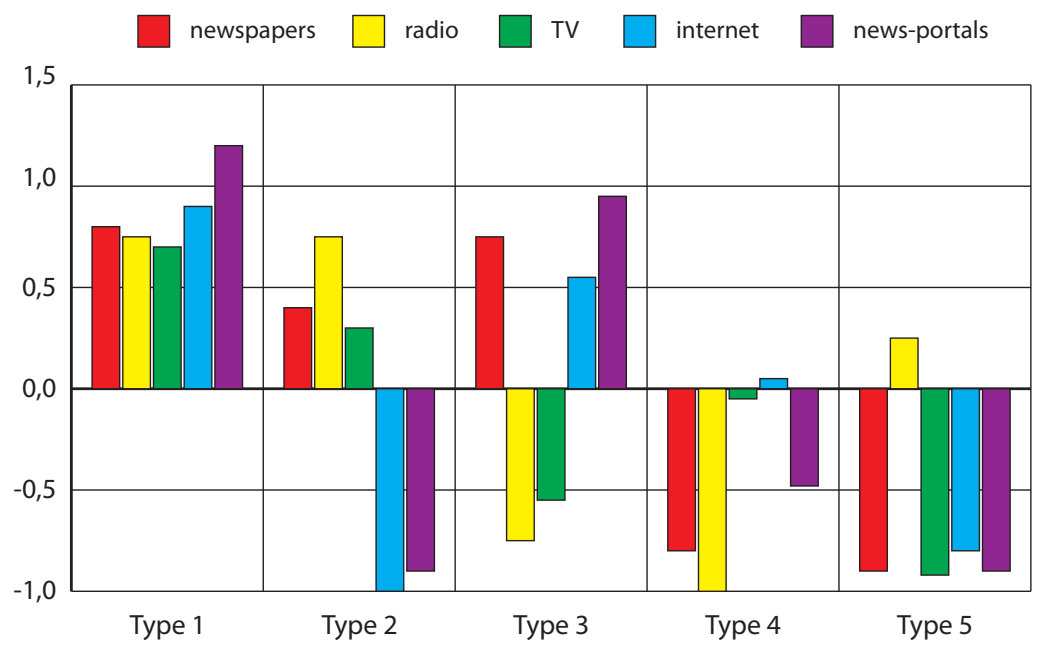

If we compare media trust, trust in state institutions and general trust (trust in other people) in the five types, we can see that they are clearly polarised: the most passive group is the least trusting and the most active group is the most trusting (see Figure 3). The differences between groups who take a middle stance are quite small.

Figure 3: Trust in media, state institutions and general trust (trust in other people) in different media clusters (compared to averages of all respondents, $n=1510$ ) (differences are significant on the level 0.00).

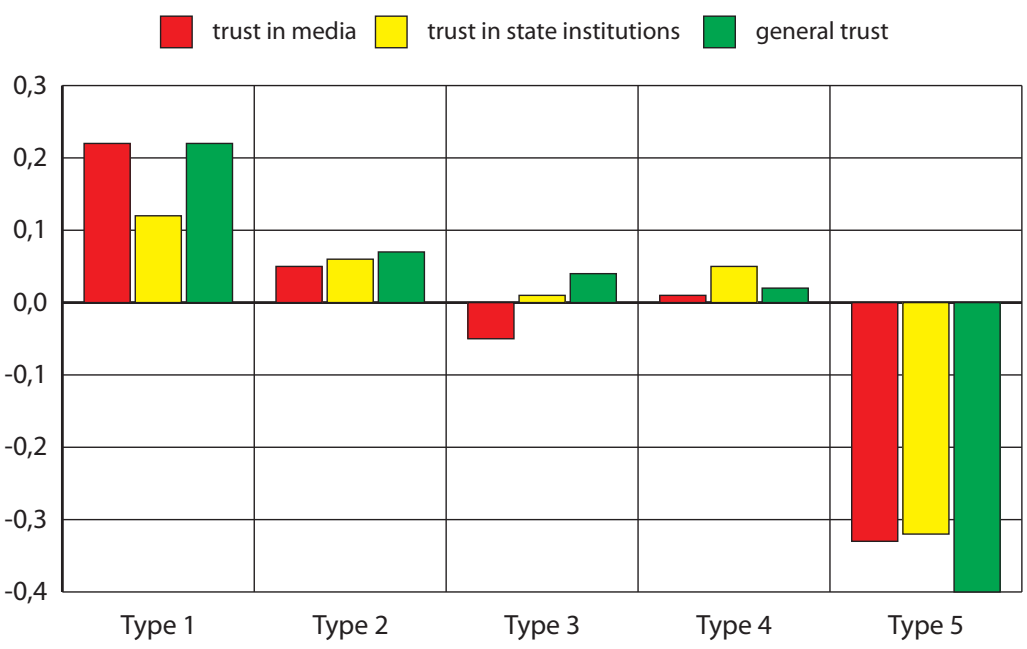


We can also show several socio-demographical country-specific results: the most passive and distrusting group consists mostly of Estonian Russianspeakers; gender has no effect on the levels of media usage, participation and trust. The age groups are divided by the preferential usage of traditional or new media, but not by the level of participation: both the oldest and the youngest respondents are divided between the active and passive groups.

\section{Trust and the 'reputation' of media channels}

Our next question was how trust in media is related to the perception of the public role of the channel. Based on theoretical and empirical literature, we assumed that channels which appeal to general public interest are more trusted than others.

If we analyse trust scores given to particular channels in the Estonian media system, we see that there are several channels that are more trusted than others. At the top of the list are the public TV and radio services, which boast significantly higher trust scores than newspapers, commercial TV and radio channels; while the least trusted media channels are internet news portals (means respectively: 3.45, 3.41, 3.07, 3.06, 3.01, 2.90 on the five-point scale). Public TV is trusted even if not as widely used, and thus we can conclude that here the channel's 'reputation' plays a significant role in the trust level granted to this channel. Nevertheless, this conclusion mainly concerns Estonian-speakers who trust public broadcasting much more than private channels. Among Russianspeakers, differences in trust levels related to different Estonian channels are much lower (Figure 4). 
Figure 4: Trust in the media among Estonian-speakers and Russian-speakers (\% of respondents who tend to trust) (differences are significant on the level 0.00).

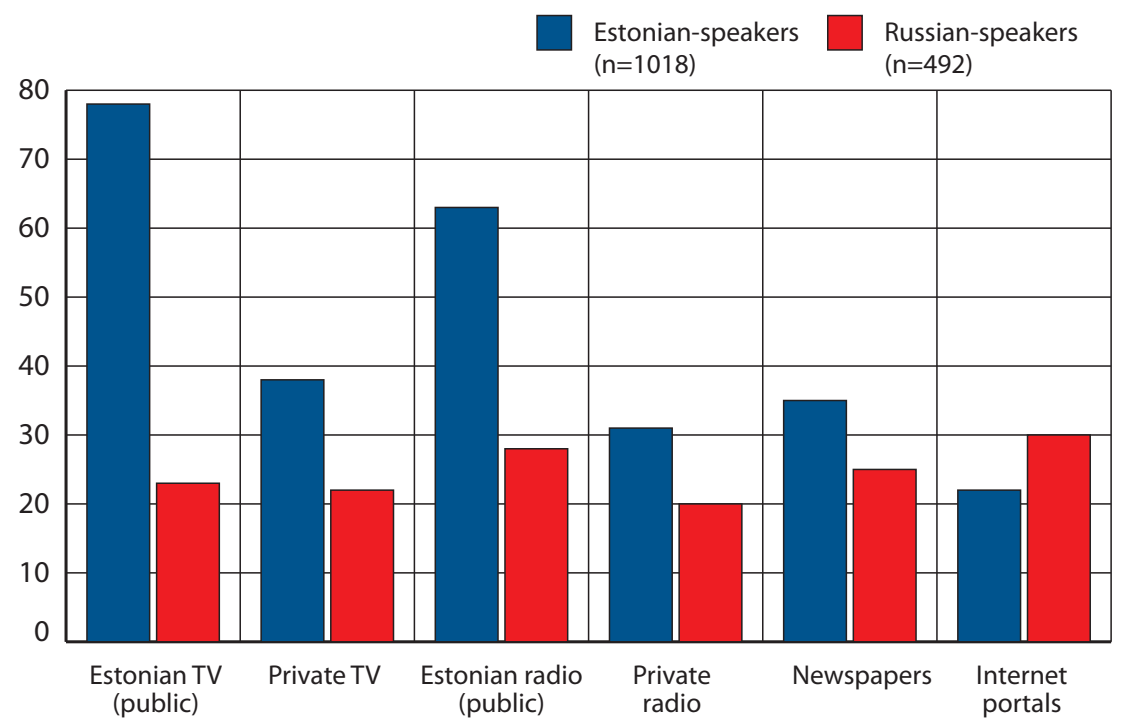

Awareness of the public or commercial orientation of a particular media channel has some impact on the assessment of trustfulness of this channel, even in the Russian audience, but it is statistically not very relevant. Low trust level in Estonian public media among Russian-speakers is strongly influenced by a relatively low level of trust in Estonian state institutions. In general, the portion of respondents with a high level of trust in the Estonian nation state is 54\% among Estonians and $27 \%$ in the Russian-speaking population; while a high level of trust in the government is $31 \%$ and $15 \%$ respectively, and in parliament, $21 \%$ and $14 \%$.

In order to analyse the hypothesis related to the importance of the 'reputation' component in trust levels among the Russian-speaking part of the audience, we chose the TV channel Pervôi Baltiiski Kanal (PBK), which broadcasts in three Baltic countries and transmits regular daily news in the programme for each country - News for Estonia, News for Latvia and News for Lithuania as an interesting and special case. The channel has the highest audience share among Russian-speakers in Estonia. PBK is a private enterprise controlled by the state-owned First Channel of Russia - a fact that is not known to most of its Estonian audience. We can use this example to indicate a pattern in which people who think that $\mathrm{PBK}$ is a public broadcasting service in Baltic countries trust this channel more than others. 
We verified the correlation between two variables: trust levels in PBK and opinions on ownership of PBK. In the questionnaire, we had five given variants regarding the ownership of PBK, namely: 1 - it is a public service channel of the Baltic States; 2 - it is a private Russian company; 3 - it is a private company registered in the Baltic States, but the owner is from Russia; 4 - it is Russian state channel; 5 - do not know.

First of all, a slight correlation (Pearson's $\mathrm{R}=0.152$ ) between these two variables exists and is significant. Those who think that PBK is a public service channel of the Baltic states trust the channel more than those who do not know who the 'owner' of PBK is (see Figure 5).

Figure 5: Trust in TV channel PBK (First Baltic Channel, owned by Russian state) depending on the opinion given in relation to the channel's ownership (\% of respondents, $n=802$ ).

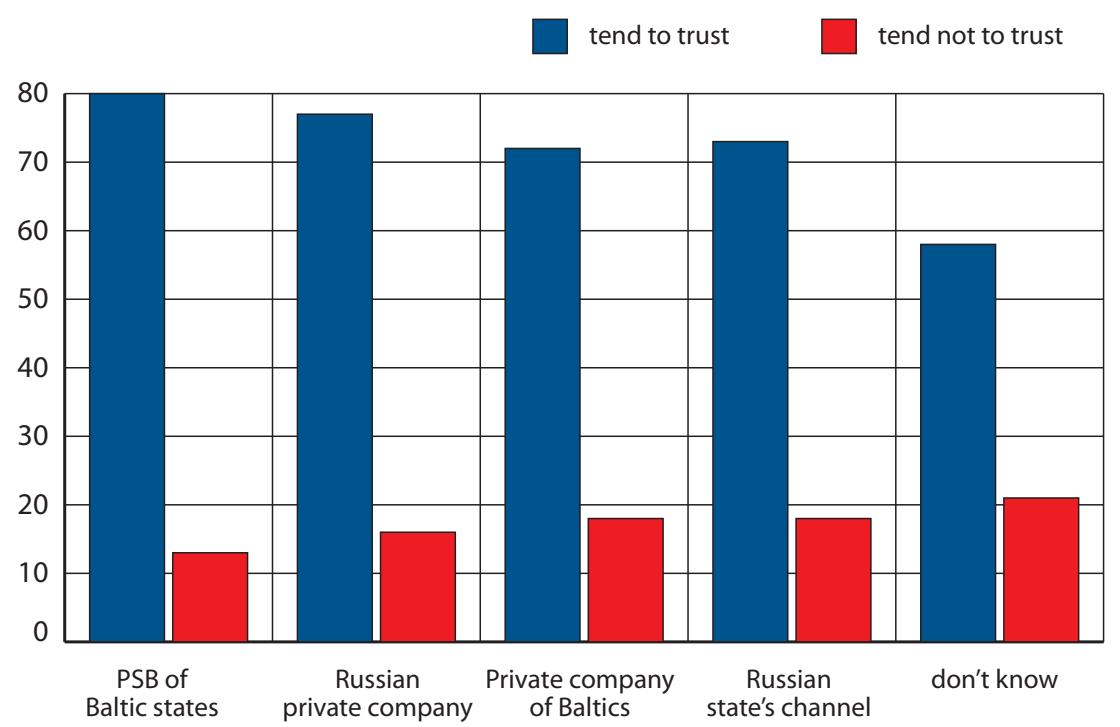

As we see in Figure 5, there is no difference in trust levels in the groups of respondents who think that the channel is privately owned, no matter where the owner comes from, i.e. from Russia or the Baltic States. If we check other possible factors which could influence trust in PBK, the actual use of PBK (B $=0.372$, the importance of PBK news for respondents) has the strongest value. This result indicates that among Russian-speakers, the actual experience of viewing (a procedural component of trust) has more importance than a channel's reputation. 
At the same time, trust in the media in this minority language group is affected by identity orientation (see Figure 6).

Figure 6: Trust in media channels depending on the identification with Estonia or Russia as their homeland (\% of respondents, $n=802$ ).

\section{Trust of Russian minority in Russian language media related to identity orientation}

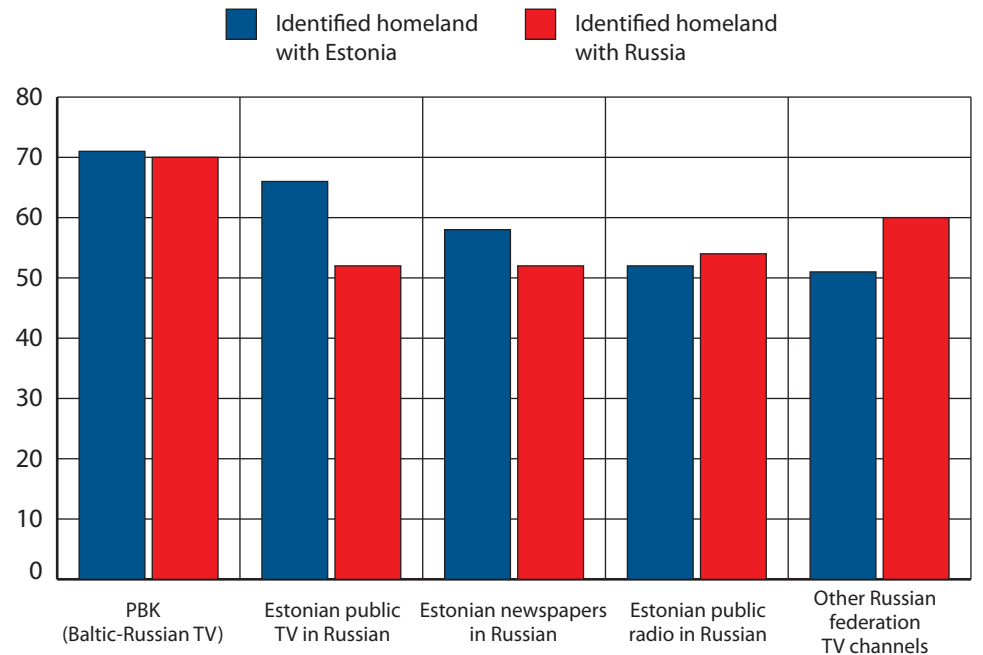

Members of the Russian minority who are better integrated into Estonian society and identify Estonia as their only homeland, show less trust in TV channels originating in the Russian Federation when compared to those who identify Russia as their only homeland, even if the regularity with which they watch these channels is equal. The only exception here is again PBK, whose connection with Russia is unclear to the audience, even if the share of local content is relatively high.

\section{Conclusions and discussion}

In many countries in Europe, trust in the media is positively correlated with trust in state institutions. In Northern Europe, Austria, Germany and Belgium, trust levels in the media and trust in state institutions are both high. As former communist countries, Estonia and Bulgaria also belong to this pattern. Low trust levels, both in state institutions and in the media, are characteristic of 
Greece, Italy and Malta. Other countries represent ambivalent patterns, where one trust score is lower and the other is higher or both correspond to the EU average. Very low trust in the media is evident in Spain, Hungary and the UK. The internet is the least trusted media channel in Europe, but in several countries the internet has a higher trust level when compared to 'traditional' channels (e.g. Greece and Italy). This result is important and we should probably re-think the role of the media and of particular media types in Europe in future.

Our interest lay in the foundations of trust in the media within the context of audience fragmentation, where there is no single, unifying core of media usage for audiences and different groups have clearly distinguishable media 'menus'. Patterns of audience fragmentation show that there are no clear sociodemographic divisions between more or less active, traditional or new media users, but it is possible to distinguish between groups of active users of traditional and 'new' media, groups with an exclusively 'new' media orientation, groups with an exclusively traditional media orientation, and even groups where media use is rather low.

Using the model offered by Piotr Szrompka (1999), we focused on the importance of two components in institutional trust: the procedural component (media use) and the 'reputation' component (the perceived public role of channels). Does the trust in media grow from actual use or rather, does it derive from the more abstract, perceived role of the media in the national context? We used data from a comprehensive survey carried out in Estonia in 2011 to test this enquiry.

Only one conclusion can be drawn - active and diverse media use is related to higher participation in social life and to higher institutional trust, and vice versa - less active and rather one-dimensional media use is related to low levels of participation and institutional trust. This said, it is not possible to talk about causal relationships in this context. We do not know if more diverse media use results in a more trusting attitude, or whether diverse media use is related to a more trusting attitude. We should agree with Delhey and Newton, who, after extensive research, can only say: "we can say rather little about causes and effects" (2004: 23).

We cannot draw a single, unanimous conclusion related to the importance of the use or reputation components in media trust. Based on our data, we can see that 'cultural' factors intervene in analysed trust patterns. The perceived public roles of channels have a stronger impact on trust in only one analysed group with a different cultural background - in our case, that of the Estonian-speakers 
in Estonia. The Russian-speaking part of the audience does not consider the distinction between public service and commercial outlets as being significant, while trust levels in different media channels within this group mainly rely on the component of actual use - procedural trust. Thus, we can only conclude that in every single culture, the composition of trust follows cultural patterns. In some cultural groups, trust rests mainly on usage practices - the audience's trust rises with the usage of the channel; in other cultural groups, the trustworthy image of the media plays a more important role - they trust when they believe that the channel acts in public interest or for the common good, as the public media service is perceived to do in many European countries.

Our study confirms some well-known patterns and correlations between trust in the media and trust in political institutions, but also adds some new complexities to such patterns. We showed that national and cultural contexts in one country play a decisive role, although they are sometimes glossed over in the grand comparisons of trust levels across many national frontiers, where the conditions - and therefore also findings - are sometimes incommensurable. 


\section{References}

Cappella, J. N. (2002). Cynicism and Social Trust in the New Media Environment. Journal of Communication, 52(1), 229-241.

Carpentier, N. \& Dahlgren, P. (2011). Introduction: Interrogating audiences - Theoretical horizons of participation. CM-Communication Management Quarterly, 6(21), 7-12.

Chaffee, S. \& Metzger, M. J. (2001) The End of Mass Communication?. Mass Communication and Society, 4(4), 365-379.

Dahlgren, P. (2011). Parameters of Online Participation: Conceptualising Civic Contingencies. CM-Communication Management Quarterly, 6(21), 87-110.

Delhey, J. \& Newton, K. (2002). Who Trusts? The Origins of Social Trust in Seven Nations. WZB discussion papers, FS III 02-402. Berlin: Social Science Research Centre Berlin.

Delhey, J. \& Newton, K. (2005). Predicting Cross-National Levels of Social Trust: Global Pattern or Nordic Exceptionalism?. European Sociological Review, 21(4), 311-327.

Esser, F. \& Hanitsch, T. (2012). Introduction: On the Why and How of Comparative Inquiry in Communication Studies. In Esser, F. \& Hanitzsch, T. (eds.), The Handbook of Comparative Communication Research. New York and London: Routledge, pp. 3-22.

Standard Eurobarometer (2006). Full Report, 65. Accessed 03.06.2012. URL: http://ec.europa.eu/public_opinion/archives/eb/eb65/eb65_en.htm.

Standard Eurobarometer (2009). Public Opinion in the European Union, 71. Accessed 03.06.2012. URL: http://ec.europa.eu/public_opinion/archives/ eb/eb71/eb71_en.htm

Standard Eurobarometer (2011). Public Opinion in the European Union, 75. Accessed 03.06.2012. http://ec.europa.eu/public_opinion/archives/eb/ eb75/eb75_en.htm

Gerbner, G. et al. (eds.) (1969). The Analysis of Communication Content: Developments in Scientific Theories and Computer Techniques. New York: Wiley. Gordon, T. (ed.) (2003). Marshall McLuhan. Understanding media: The Extensions of Man. Critical edition. Corte Madera, CA: Gingko Press. 
Hallin, D. C. \& Mancini, P. (2004). Comparing Media Systems: Three Models of Media and Politics. Cambridge: Cambridge University Press.

Heitmeyer, W. (ed.) (1997). Was hält die Gesellschaft zusammen? Frankfurt a.M: Opladen.

Jakubowicz, K. (2010). Introduction: Media Systems Research: An Overview. Boguslawa, D-O (ed.), Comparative Media Systems: European and Global Perspectives. Budapest, New York: Central European University Press, pp. $1-21$.

Jóesaar, A. (2011). EU media policy and survival of public service broadcasting in Estonia 1994-2010. Dissertationes de mediis et communicatioibus Universitatis Tartuensis, 14. Tartu: Tartu University Press.

Kouts, R. (2004). Social Integration in the Post-Socialist Society: The Case of Estonia. BaltSeaNet. Gdansk, Berlin: Nordeuropa Institut der HumboldtUniversität zu Berlin.

Lauristin, M., Vihalemm, P., Uus, S. \& Peegel, J. (1987). Rajoonileht ja lugeja [Local paper and it's Reader]. Tallinn: Eesti Raamat.

Lovell, D. W. (2001). Trust and Politics of Post-communism. Communist and Post-Communist Studies, 34(1), 27-38.

Luhmann, N. (2002). Theories of Distinction. Edited, with an Introduction, by W. Rasch. Stanford: Stanford University Press.

McQuail, D. (2007). Introduction. The Current State of Media Governance in Europe. In Terzis, G. (ed.), European Media Governance, National and Regional Dimensions. Bristol, UK/ Chicago, USA: Intellect, pp. 17-25.

Media Use in the EU - Autumn 2011. (2011). Standard Eurobarometer 76.

Mishler, W. \& Rose, R. (2001). What Are the Origins of Political Trust?. Comparative Political Studies, 34(1), 30-62.

Moy, P. \& Pfau, M. (2000). With Malice Toward All? The Media and Public Confidence in Democratic Institutions. Westport, CT: Praeger.

Moy, P. \& Scheufele, D. A. (2000). Media Effects on Political and Social Trust. Journalism and Mass Communication Quarterly, 77(4), 744-759.

Putnam, R. D. (2000). Bowling Alone. New York: Simon \& Schuster.

Quandt, T. (2012). What's Left of Trust in a Network Society? An Evolutionary Model and Critical Discussion of Trust and Societal Communication. European Journal of Communication, 27(1), 7-21. 
Schulz, W. (1999). Fernsehen und sozialer Wandel: Untersuchungen zur Integrations- und Fragmentierungsthese. In Wilke, J. (Hrsg.), Massenmedien und Zeitgeschichte. Schriftenreihe der Deutschen Gesellschaft für Publizistikund Kommunikationswissenschaft. Band 26. UVK Medien, pp. 90-105.

Siebert, F. S., Peterson, T. \& Schramm, W. (1963). Four Theories of the Press. Urbana and Chicago: University of Illinois Press.

Sztompka, P. (1995). Vertrauen: Die fehlende Ressource in der postkommunistischen Gesellschaft. Kölner Zeitschrift für Soziologie und Sozialpsychologie, Sonderheft 35, 254-276.

Sztompka, P. (1999). Trust. A Sociological Theory. Cambridge: Cambridge University Press.

Tewksbury, D. (2005). The Seeds of Audience Fragmentation: Specialization in the Use of Online News Sites. Journal of Broadcasting and Electronic Media, 49(3), 332-348.

Vihalemm, P. (2008). Current Trends of Media Use in Estonia. Informacijos Mokslai, 47, 112-120. Accessed 03.06.2012. URL: www.leidykla.eu/fileadmin/Informacijos_mokslai/47/112-120.pdf.

Webster, J. G. \& Ksiazek, T. B. (2012). The Dynamics of Audience Fragmentation: Public Attention in an Age of Digital Media. Journal of Communication, 62(1), 39-56.

Wolling, J. (2001). Skandalberichterstattung in den Medien und die Folgen für die Demokratie. Publizistik, 46(1), 20-36. 


\section{Annexe}

Media usage cluster profiles (differences in the means compared to the means of all respondents on the five-point scale; means which are higher than the mean for all respondents are presented in bold type)

\begin{tabular}{|c|c|c|c|c|c|c|}
\hline & Type 1 & Type 2 & Type 3 & Type 4 & Type 5 & Total \\
\hline Cluster's label & $\begin{array}{l}\text { Multi- } \\
\text { active }\end{array}$ & $\begin{array}{l}\text { Active } \\
\text { traditional } \\
\text { user }\end{array}$ & $\begin{array}{l}\text { Reading- } \\
\text { oriented } \\
\text { moderate } \\
\text { user }\end{array}$ & $\begin{array}{l}\text { Moderate } \\
\text { TV and } \\
\text { internet } \\
\text { user }\end{array}$ & $\begin{array}{l}\text { Passive } \\
\text { public } \\
\text { radio } \\
\text { listener }\end{array}$ & \\
\hline $\begin{array}{l}\text { Share of cluster among } \\
\text { respondents } \\
(\%, n=1510)\end{array}$ & 22.8 & 17.3 & 13.0 & 17.5 & 29.3 & 100 \\
\hline \multicolumn{7}{|c|}{ Media use indexes, activeness and diversity in: } \\
\hline newspaper reading & 3.96 & 3.43 & 3.80 & 2.24 & 2.14 & 3.02 \\
\hline radio listening & 3.92 & 3.80 & 2.21 & 2.02 & 3.30 & 3.01 \\
\hline TV viewing & 3.86 & 3.38 & 2.47 & 3.00 & 2.11 & 3.04 \\
\hline internet use & 3.97 & 2.00 & 3.54 & 3.02 & 2.25 & 2.99 \\
\hline news portal reading & 4.23 & 1.98 & 3.83 & 2.37 & 1.95 & 2.84 \\
\hline \multicolumn{7}{|c|}{ Civic and political participation indexes } \\
\hline $\begin{array}{l}\text { General interest in politics } \\
\text { and political participation }\end{array}$ & 3.77 & 3.48 & 3.04 & 2.77 & 2.09 & 3.04 \\
\hline $\begin{array}{l}\text { Participation in civic } \\
\text { actions }\end{array}$ & 3.44 & 3.24 & 2.39 & 2.60 & 1.56 & 2.69 \\
\hline \multicolumn{7}{|l|}{ Trust variables } \\
\hline Trust in media & 3.34 & 3.18 & 3.09 & 3.13 & 2.78 & 3.12 \\
\hline Trust in state institutions & 3.08 & 3.04 & 2.98 & 3.04 & 2.64 & 2.97 \\
\hline General social trust & 3.21 & 3.07 & 3.03 & 3.01 & 2.59 & 2.99 \\
\hline \multicolumn{7}{|l|}{$\begin{array}{l}\text { Additional variables } \\
\text { characterising the types }\end{array}$} \\
\hline $\begin{array}{l}\text { Critical attitude towards } \\
\text { Estonian media }\end{array}$ & 3.15 & 2.93 & 3.08 & 2.80 & 2.67 & 2.92 \\
\hline Optimistic attitude & 2.70 & 2.20 & 2.62 & 2.45 & 1.83 & 2.38 \\
\hline $\begin{array}{l}\text { Positive evaluation of } \\
\text { social changes }\end{array}$ & 3.56 & 3.28 & 3.39 & 3.26 & 2.90 & 3.29 \\
\hline $\begin{array}{l}\text { Broad use of foreign } \\
\text { languages }\end{array}$ & 3.60 & 2.83 & 3.10 & 3.02 & 2.52 & 3.04 \\
\hline $\begin{array}{l}\text { Personal experiences in the } \\
\text { western world }\end{array}$ & 3.07 & 2.34 & 2.90 & 2.54 & 2.00 & 2.58 \\
\hline
\end{tabular}


Ragne Kõuts,

Peeter Vihalemm, Marju Lauristin
Trust in the context of audience fragmentation

Socio-demographic composition of clusters

\begin{tabular}{|c|c|c|c|c|c|c|}
\hline & Type 1 & Type 2 & Type 3 & Type 4 & Type 5 & Total \\
\hline Cluster's label & $\begin{array}{l}\text { Multi- } \\
\text { active }\end{array}$ & $\begin{array}{c}\text { Active } \\
\text { traditional } \\
\text { user }\end{array}$ & $\begin{array}{c}\text { Reading- } \\
\text { oriented } \\
\text { moderate } \\
\text { user } \\
\end{array}$ & $\begin{array}{c}\text { Moderate } \\
\text { TV and } \\
\text { internet } \\
\text { user } \\
\end{array}$ & $\begin{array}{l}\text { Passive } \\
\text { public } \\
\text { radio } \\
\text { listener }\end{array}$ & \\
\hline $\begin{array}{l}\text { Share of cluster } \\
\text { among respondents } \\
(\%, \mathrm{n}=1510)\end{array}$ & 22.8 & 17.3 & 13.0 & 17.5 & 29.3 & 100 \\
\hline $\begin{array}{l}\text { Language for } \\
\text { answering } \\
\text { Estonian } \\
\text { Russian }\end{array}$ & $\begin{array}{l}\mathbf{8 0 . 6} \\
19.4\end{array}$ & $\begin{array}{l}74.7 \\
25.3\end{array}$ & $\begin{array}{l}\mathbf{8 0 . 2} \\
19.8\end{array}$ & $\begin{array}{l}69.3 \\
30.7\end{array}$ & $\begin{array}{l}36.0 \\
\mathbf{6 4 . 0}\end{array}$ & $\begin{array}{l}68.4 \\
31.6\end{array}$ \\
\hline $\begin{array}{l}\text { Gender } \\
\text { Male } \\
\text { Female } \\
\end{array}$ & $\begin{array}{l}48.7 \\
51.3 \\
\end{array}$ & $\begin{array}{r}50.2 \\
49.8 \\
\end{array}$ & $\begin{array}{l}40.1 \\
\mathbf{5 9 . 9}\end{array}$ & $\begin{array}{l}41.5 \\
58.5\end{array}$ & $\begin{array}{r}\mathbf{5 3 . 8} \\
46.2 \\
\end{array}$ & $\begin{array}{l}46.6 \\
53.4\end{array}$ \\
\hline $\begin{array}{l}\text { Age } \\
15-19 \\
20-29 \\
30-44 \\
45-54 \\
55-64 \\
65-74\end{array}$ & $\begin{array}{c}4.3 \\
17.7 \\
\mathbf{3 4 . 8} \\
\mathbf{2 2 . 0} \\
16.2 \\
4.9\end{array}$ & $\begin{array}{c}2.3 \\
4.2 \\
17.6 \\
\mathbf{2 4 . 1} \\
\mathbf{2 3 . 8} \\
\mathbf{2 8 . 0}\end{array}$ & $\begin{array}{c}6.6 \\
27.9 \\
32.0 \\
16.8 \\
12.7 \\
4.1\end{array}$ & $\begin{array}{c}\mathbf{1 3 . 5} \\
\mathbf{2 4 . 6} \\
24.4 \\
13.5 \\
16.5 \\
7.4\end{array}$ & $\begin{array}{c}8.7 \\
17.4 \\
21.6 \\
20.1 \\
13.3 \\
\mathbf{1 8 . 9}\end{array}$ & $\begin{array}{c}7.7 \\
18.7 \\
26.1 \\
18.9 \\
16.6 \\
12.0\end{array}$ \\
\hline $\begin{array}{l}\text { Income per individual } \\
\text { per month } \\
\text { Below } 160 \text { euro } \\
161-250 \\
251-400 \\
401-600 \\
\text { Over } 600 \text { euro }\end{array}$ & $\begin{array}{l}14.8 \\
15.4 \\
24.3 \\
\mathbf{2 7 . 5} \\
\mathbf{1 6 . 2} \\
\end{array}$ & $\begin{array}{c}17.6 \\
18.4 \\
38.7 \\
16.5 \\
8.0 \\
\end{array}$ & $\begin{array}{l}18.3 \\
14.2 \\
27.4 \\
\mathbf{2 1 . 3} \\
\mathbf{1 6 . 8} \\
\end{array}$ & $\begin{array}{l}22.8 \\
16.5 \\
28.9 \\
19.0 \\
11.5 \\
\end{array}$ & $\begin{array}{c}19.3 \\
26.5 \\
33.3 \\
12.9 \\
6.4 \\
\end{array}$ & $\begin{array}{l}18.9 \\
18.0 \\
30.1 \\
19.7 \\
11.8 \\
\end{array}$ \\
\hline $\begin{array}{l}\text { Education } \\
\text { Primary } \\
\text { Secondary } \\
\text { Tertiary }\end{array}$ & $\begin{array}{l}11.3 \\
52.2 \\
36.5\end{array}$ & $\begin{array}{l}18.0 \\
\mathbf{6 1 . 7} \\
20.3\end{array}$ & $\begin{array}{l}12.7 \\
51.3 \\
\mathbf{3 6 . 0}\end{array}$ & $\begin{array}{l}23.5 \\
53.3 \\
23.3\end{array}$ & $\begin{array}{l}\mathbf{3 0 . 3} \\
54.9 \\
14.8\end{array}$ & $\begin{array}{l}19.5 \\
54.5 \\
26.0\end{array}$ \\
\hline
\end{tabular}

